\title{
Using Graded Peer Evaluation To Improve Students' Writing Skills, Critical Thinking Ability, And Comprehension Of Material In A Principles Of Public Relations Course
}

Vicki Todd, (E-mail: Vicki.Todd@quinnipiac.edu), Quinnipiac University Jerry C. Hudson, (E-mail: jerry.hudson @ttu.edu), Texas Tech University

\begin{abstract}
This peer-evaluation assignment encouraged students to think critically, synthesize information and write about public relations course material rather than incorporate surface information into written assignments. Because peer reviewers can improve the grades on their final papers by offering concrete suggestions to the original authors, students tended to report that the peerevaluation process improved their writing skills, critical thinking ability, and their understanding of public relations concepts and theories. This research demonstrates how peer evaluation can be a positive learning exercise that prompts students to develop higher-order cognitive skills and to improve their writing skills while learning discipline-specific course concepts.
\end{abstract}

\section{INTRODUCTION}

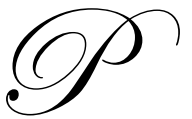

eer evaluation, according to Gueldenzoph and May, is a means of assessment that allows students to participate in the assessment process by evaluating a classmate's written work, but the final grade for students' work is determined by the course instructor. ${ }^{1}$ Cho, Schunn and Charney add that although peer evaluation is a commonly used teaching technique in undergraduate classrooms, the practice of peer review has been studied infrequently. These researchers assert that students benefit from the peer evaluation process through commenting on their peers' written work and from reading comments that peers have made on their papers. ${ }^{2}$ Topping agrees that peer evaluation is beneficial to students' learning of course material, because it serves as formative assessment that "aims to improve learning while it is happening in order to maximize success rather than merely determine success or failure only after the event." Topping continues by stating that peer evaluation benefits assessors and assessees by: (1) prompting higher order thinking; (2) enhancing students' time on task, engagement, and sense of accountability; (3) helping students identify and fill in knowledge gaps in their work; and (4) encouraging active rather than passive learning in students. ${ }^{3}$ Jensen and Fischer concur that students' increased time and effort during the peer evaluation process seems to progress students' writing skills through commenting on their peers' written mistakes and developing suggestions of how students can improve these mistakes. ${ }^{4}$

The peer evaluation process can also affect students' final paper grades and the quality of students' written work. For example, Jensen and Fischer compared students' written reports, which were graded by either a teaching assistant or instructor in one section of a course or by peer evaluators using the same grading criteria in another section of the same course. The students who participated in the peer evaluation section earned higher grades than the students whose papers were graded by the instructor or teaching assistant. Jensen and Fischer surmise that the peer evaluation process positively affected the writing skills of the students who took part in the peer review procedure resulting in higher quality written products. ${ }^{5}$ 
Reese-Durham agrees that the peer evaluation process can serve as a learning activity for students, which can result in a more polished final written product. This researcher reported that the quality of papers from students who participated in her peer evaluation study was "significantly higher than papers collected from previous classes." Reese-Durham adds that allowing students to evaluate a classmate's first draft of a paper can help reduce the intimidation and loss of self-esteem that may occur when the professor marks the first versions of students' written assignments. ${ }^{6}$ However, Cho, Schunn, and Charney report that students have expressed concern that peer evaluation is not a fair process because peers may not take their assessment responsibilities seriously and because students are not qualified to make comments or suggestions about other students' work. ${ }^{7}$ Chen and Lou are of the same opinion regarding students' reluctance to take peer evaluation assignments seriously. These researchers state that "if peer evaluations are used for purposes that students do not value, or they see no visible results from their participatory efforts, they will cease to give meaningful input." These researchers suggest that professors clearly inform the students of the purpose of the peer evaluation process and assure students that their feedback will be used in the professor's evaluation of the students' work to encourage them to participate in the peer review process. ${ }^{8}$

\section{WRITING SKILLS ESSENTIAL IN MASS COMMUNICATIONS}

Wiltse suggests that writing is a crucial skill for students enrolled in mass communications programs to develop and to master. ${ }^{9}$ Likewise, Birge reports that newspaper editors seek graduates who are strong writers and critical thinkers more so than students who possess multimedia skills but insufficient writing skills. ${ }^{10}$ Budig emphasizes the importance of strong writing skills in college graduates by referencing The College Board's National Commission on Writing, which was sent to Congress in 2004. According to one of the Board's reports, titled Writing: A Ticket to Work...Or a Ticket Out, "people who cannot write and communicate clearly are less likely to be hired than people who have these skills, and, if hired, they are unlikely to last long enough to be considered for promotion." Furthermore, half of the company officials surveyed for the report stated that they take applicants' writing skills into consideration when searching for new employees. ${ }^{11}$

Several academicians and industry professionals have offered advice regarding how students can become more proficient writers. For example, LaRocque cautions against wordiness in media writing that can reduce the accuracy, brevity, and clarity of communication messages. ${ }^{12}$ LaRocque also urges media writers to write more effectively by creating direct statements that come to an emphatic point without "backing into" a sentence or paragraph. ${ }^{13}$ Rose recommends other advice for media writers to help them attract and retain target audience readers. These tips include: (1) determining the most important element of the story and fashioning an attention-getting lead around this information; (2) telling stories that compel media gatekeepers and target audiences alike; (3) using vivid images in writing to which readers can relate; (4) employing simple language that avoids unfamiliar acronyms and jargon; (5) writing with active voice verbs to emphasize who or what has done the action in the communication messages; (6) avoiding factual, grammatical, and punctuation errors, as well as misspelled words that can reduce media writers' credibility among target audience members; and (7) revising media writing to develop clear and effective communication messages. ${ }^{14}$

Furthermore, Wiltse surmises that writing apprehension, writing experience, and writing outcomes expectations can help predict students' choice of major area of study. For example, students with less writing apprehension will select majors that include more writing requirements, such as journalism, while students who are more writing apprehensive will choose majors that require less perceived writing, such as non-communications fields of study. Also, Wiltse found that writing experience and writing outcomes expectations among students had a positive relationship with the writing apprehension dimension. This researcher urges mass communications professors to provide students with several writing opportunities, because students who write more often experience less writing apprehension. ${ }^{15}$ 


\section{DEVELOPING AND TEACHING CRITICAL THINKING SKILLS}

In addition to effective writing skills, Burbach, Matkin, and Fritz state that employers expect employees to possess critical thinking ability. ${ }^{16}$ Pithers and Soden affirm that college graduates are expected to learn disciplinespecific material, as well as generic abilities such as critical thinking skills. ${ }^{17}$ Although consensus regarding a definition of critical thinking does not currently exist, researchers frequently cite the last four categories of Bloom's taxonomy of educational objectives. ${ }^{18}$ According to Bissell and Lemons, "the first two categories, basic knowledge and secondary comprehension, do not require critical-thinking skills, but the last four - application, analysis, synthesis, and evaluation - all require the higher-order thinking that characterizes critical thought." ${ }^{19}$ However, Lauer argues that most students focus on the lower-order cognitive skills of knowledge and comprehension, which separates course content from higher-order cognitive skills and blocks students' learning of course material. ${ }^{20}$ To help students become more adept critical thinkers, Vesely and Sherlock emphasize that professors must teach students to identify vital questions and problems, gather and synthesize relevant information, develop and substantiate well-thought out conclusions, and communicate their findings to appropriate audiences. ${ }^{21}$

Other researchers suggest teaching techniques that educators can use to assist students in developing critical thinking skills. For example, Black suggests that professors place students' thinking processes at the center of all classroom lessons, state explicit purposes and goals of learning exercises, and create a classroom environment that is conducive to students' free expression of divergent opinions. ${ }^{22}$ Burbach, Matkin, and Fritz urge educators to integrate critical thinking skills into discipline-based courses. These researchers surmise that active learning strategies, such as journal writing, small groups, and case studies can enable students to improve their critical thinking abilities while they learn the content of their chosen discipline. ${ }^{23}$ Finally, Gammill asserts that writing to learn exercises play a role in encouraging students to develop metacognitive and reasoning skills, as well as the ability to analyze and synthesize information, which helps them more effectively learn course content. ${ }^{24}$

The researcher conducted three focus groups of students at a large private university in the fall 2006 semester to determine their attitudes about writing to learn (WTL) assignments. During these focus groups, the research discovered some negative student attitudes about assignments using peer evaluation processes. The majority of students tended not to take peer-reviewed assignments seriously if they were not graded on their review comments, while a large proportion of other students assumed peer reviewed assignments to be busy work that eases the teaching load of the course instructor. These findings prompted the researcher to develop the graded peerevaluation assignment that was utilized and tested in this research project.

Based on the focus group comments and the literature regarding writing skills, critical thinking skills and the importance of understanding public relations terms and concepts, the researcher developed the following research questions about peer review processes.

R1: Do peer evaluations increase student writing skills?

R2: Do peer evaluations increase student critical thinking skills?

R3: Do peer evaluations increase student knowledge about public relations?

\section{Method}

Peer Review Method

The purposes of the peer review assignments in a Principles of Public Relations course were to teach students to (1) think more critically about the issues and practices of public relations, (2) synthesize textbook material and apply this information to public relations practices, and (3) increase writing skills. To address these purposes, the researcher modified a writing to learn (WTL) assignment into a three-component graded peerreviewed activity. 
Students were required to identify a magazine advocacy advertisement that attempted to persuade or promoted advocacy for an issue or cause. Students were asked to explain why their chosen advocacy ad defines or relates to public relations by using concepts, models, and theories covered in the text chapters involving communications, ethics, program planning, and/or persuasion aspects. Each of the drafts addressed only information covered in assigned chapters that related to specific characteristics of the advertisements. The first assignment required students to evaluate the advertisement's audience(s) based on its message, publication, topic and request for action. The second assignment concentrated on the communication or message. Students analyzed the message's use of language/terms, communication theories or persuasive techniques, design of the advertisement, and their perceived effectiveness of the advertisement. The final paper combined the first two assignments with appropriate corrections and modifications.

Students used four elements of the peer review process that included instructions for writing the draft of each assignment, a grading rubric developed by the researcher for students to follow when they graded their peer's drafts, criteria used by the instructor to grade the peer reviewers' evaluation of the drafts, and the final or corrected paper assignment.

After students completed their first draft assignment, the instructor randomly redistributed the students' papers and the corresponding advocacy ads to anonymous peer reviewers. Anonymity in the peer evaluation process is important because "efforts to get students to critique peer writing often fail because peer critiquing violates student social norms of not criticizing other students in the presence of a teacher." ${ }^{25}$ All students were given a peer evaluation instruction sheet to assist them in assessing their classmate's paper along with the grading rubric. The instruction sheet included checklists of chapter information to help reviewers identify deficiencies in their peer's written work. According to Topping, specific chapter checklists are important to help students clarify how to evaluate a peer's paper rather than providing students with vague assessment criteria. ${ }^{26}$ The instruction sheet also provided peer reviewers with a point scale detailing how they would be graded on their peer evaluation comments. After the students evaluated their peer's work, the instructor also graded the students' original draft and the comments provided by peer evaluators. The students writing the draft and the peer reviewers demonstrated their level of knowledge or understanding of the material for the respective assignment. Therefore, students writing the drafts and the peer reviewers each received a grade from the instructor.

When the drafts and the peer reviews were returned to the students, the class engaged in discussions about the peer review and instructor comments. Students had an opportunity to defend their peer reviews, while the student authors of the original draft could challenge the peer and instructor comments. This process was repeated for the second draft of the assignment before students revised and submitted their final papers.

\section{Research Methods}

The researcher utilized two methods for addressing the three research questions. Students attending a class two weeks before the end of the fall 2006 and spring 2007 semesters completed a questionnaire. During the last week of classes each semester, two groups of 10 students participated in a focus group conducted by the researcher.

A questionnaire including 23 statements about the peer review exercises was distributed to 25 students during the fall 2006 semester and 32 students during the spring 2007 semester. The statements were written in a positive way about student gains in knowledge about public relations, writing skills, critical thinking skills, and the value of the peer review processes. Students rated the statements using a seven point Likert-type scale where a rating of one represented a strong disagreement with the statement and a rating of seven represented a strong agreement with the statement. The ratings of all 57 students were collapsed into one mean score for each question. The questions were then grouped and ranked within each of their respective categories related to writing skills, critical thinking skills, knowledge of public relations, and the peer review processes. The researcher used descriptive statistics only because of the small number of responses. 
To validate and more clearly understand the quantitative data, the researcher conducted a focus group each semester. Students were paid fifteen dollars each to participate in the focus groups. Students were asked to describe their opinions about the peer review processes regarding possible increases in their writing skills, critical thinking skills, knowledge about public relations, and class discussions of the peer reviews.

\section{RESULTS}

\section{R1: Do Peer Evaluations Increase Student Writing Skills?}

Students were positive about the peer review processes making contributions to their writing skills. The mean scores for each of the writing skill statements ranged from 4.8 to 5.6 on a scale of one to seven (Table 1). Students indicated that they increased their writing skills from the comments provided by their peer reviewer regarding spelling, grammar and punctuation; however, they indicated that their own evaluations of their peers' work tended to be more beneficial than the comments provided by their peers. This suggests that students were most likely to increase their writing skills by grading or evaluating other students' work.

These mean ratings were supported by student comments in the focus groups. Students said they tended to be more critical of other students' work and paid more attention to writing errors because they needed to justify why they did or did not make comments about errors in spelling, grammar and punctuation. They also wanted to earn the grade for providing quality comments about peer papers.

Students in the focus groups said they enjoyed class discussions about comments from peer reviewers. Students rated class discussions about writing skills at a mean of 4.9. Students also said the discussions helped them understand why peer reviewers marked the writing errors. They also liked the comments provided by the instructor to support or disagree with the peer reviewers.

\section{Table 1}

\section{Student Ratings Of Peer Evaluations And Impact On Writing Skills}

\section{Writing Skill Statement}

1. The peer review process helped increase my writing skills.

2. My reviews of my peers' papers were beneficial to me for identifying errors in spelling.

3. My reviews of my peers' papers were beneficial to me for identifying errors in grammar.

4. Comments provided by my peer reviewers of my papers were beneficial to me for identifying errors in punctuation.

5. My reviews of my peers' papers were beneficial to me for identifying errors in punctuation.

6. The class discussions about the comments written by my peer evaluator caused me to be more conscious about writing skills.

7. Comments provided by my peer reviewers of my papers were beneficial to me for identifying errors in spelling.

8. Comments provided by my peer reviewers of my papers were beneficial to me for identifying errors in grammar.

$\begin{array}{cc}\begin{array}{c}\text { Mean } \\ (\mathbf{N}=57) \\ 5.6\end{array} & \text { sd } \\ & 1.2 \\ 5.4 & 1.1 \\ 5.2 & 1.1 \\ 5.0 & 1.3 \\ 5.0 & 1.2 \\ 4.9 & 1.0 \\ 4.9 & 1.1 \\ 4.8 & 1.0\end{array}$

\section{R2: Do Peer Evaluations Increase Student Critical Thinking Skills?}

Students tended to suggest that the peer review processes assisted them in developing critical thinking skills (Table 2). They indicated that their peer reviews of other student's work and the evaluations of their work by their peers were most beneficial in developing critical thinking skills. Students also rated the class discussions as an asset in critical thinking. 
During the focus groups, most of the students commented that they understood the material in the text better than just reading the text before a test. Students said they discussed the peer reviews and learned more about the issues or problems of public relations. They more clearly understood the application of the terms and concepts included in the text.

Table 2

Student Ratings Of Peer Evaluations And Impact On Critical Thinking Skills

\section{Critical Thinking Skills Statement}

1. The peer review process helped me develop better critical thinking skills.

2. My reviews of my peers' papers were beneficial to me for developing critical thinking skills.

3. Comments provided by my peer reviewers of my papers were beneficial to me for developing critical thinking skills.

4. The class discussions about the comments written by my peer evaluator caused me to think more critically about public relations concepts.

5. The class discussions about the comments written by my peer evaluator caused me to increase my understanding of the issues related to public relations messages.

6. The class discussions about the comments written by my peer evaluator caused me to think more critically about the practical application of public relations.

\begin{tabular}{cc}
$\begin{array}{c}\text { Mean } \\
(\mathbf{N}=57) \\
5.4\end{array}$ & sd \\
& 1.2 \\
5.1 & 1.3 \\
4.9 & 1.0 \\
4.9 & 1.1 \\
4.9 & 1.0 \\
4.7 & 1.2 \\
\hline
\end{tabular}

\section{R3: Do Peer Evaluations Increase Student Knowledge About Public Relations?}

The peer evaluations were beneficial for students to learn public relations terms, message appeals, communication theories and audience analyses (Table 3). Students indicated that their review of other students' work was more beneficial to them than were the reviews of their work by peer reviewers.

A majority of students participating in the focus groups said they learned more about public relations because the class discussions were more focused on the material. They suggested that students seem to have read the material and made more intelligent comments in the discussions than when students discuss the material without peer reviews.

A large majority of the focus group participants said they were a little apprehensive at the beginning of the semester about being graded on their evaluation of another student's work. However, after the first assignment, they realized that the review processes made them more attentive to the material and encouraged them to participate in the class discussions. If they had not received a grade for their peer reviews, they did not think they would have taken the assignment as seriously. 
Table 3

Student Ratings Of Peer Evaluations And Impact On Knowledge About Public Relations

Knowledge Statement

1. My reviews of my peers' papers were beneficial to me for learning public relations terms.

2. Comments provided by my peer reviewers of my papers were beneficial to me for learning public relations terms.

3. My reviews of my peers' papers were beneficial to me for learning communication message appeals.

4. My reviews of my peers' papers were beneficial to me for learning public relations theories.

5. My reviews of my peers' papers were beneficial to me for learning target audience analyses.

6. The class discussions about the comments written by my peer evaluator caused me to learn more about public relations.

7. Comments provided by my peer reviewers of my papers were beneficial to me for learning communication message appeals.

8. Comments provided by my peer reviewers of my papers were beneficial to me for learning target audience analyses.

9. Comments provided by my peer reviewers of my papers were beneficial to me for learning public relations theories.

\begin{tabular}{cc}
$\begin{array}{l}\text { Mean } \\
(\mathbf{N}=57)\end{array}$ & sd \\
5.5 & 1.2 \\
& \\
5.3 & 1.3 \\
& \\
5.3 & 1.1 \\
5.2 & 1.2 \\
5.2 & 1.3 \\
5.2 & 1.2 \\
5.0 & 1.2 \\
4.8 & 1.3 \\
4.7 & 1.3 \\
\hline
\end{tabular}

\section{CONCLUSIONS}

Peer reviews of student assignments can create a positive learning experience. The key to the peer review process is dependent on the students' interest in participating in the peer review assignments. The quality of the peer reviews is dependent on their knowledge of the material and in the depth of their reviews.

In this peer review exercise, students indicated they were motivated to learn the material because they were graded on the quality of their peer review. This supports previous research that suggests that students must perceive a personal benefit for participating in the peer review.

The researcher did not anticipate student reports that they learned more from their evaluation of other students' assignments than they did from the peer reviews. Students seem to learn more when they have to evaluate other students' assignments. Students studied the text more thoroughly in preparation of their grading exercises. By grading assignments, students were learning more assessment criteria and more information than they would through the traditional lecturing and test-taking methods.

Class discussions of the information and the peer reviews create an atmosphere of excitement for the material and the assignment. However, the faculty member must bring each of the discussions to a fruitful conclusion by summarizing the important comments as they relate to the material. The faculty member must bring stability and closure to the discussions and peer reviews.

\section{FUTURE RESEARCH}

The student self-reporting benefits of this peer review exercise suggest that students learned more about writing skills, public relations and critical thinking than they would have in a traditional lecture and testing method of teaching. However, this study did not measure the differences in learning between peer review and the traditional method of teaching. Future research could compare the amount of learning by using control and experimental groups of students. Identical year-end tests could be given to both groups of students to assess learning public relations terms, concepts and theories. Writing skills could be evaluated and compared between the control and experimental groups. The writing assignment could also include some cases analyses to test students' critical thinking skills. 


\section{ENDNOTES}

1. Lisa E. Gueldenzoph and Gary L. May, Collaborative Peer Evaluation: Best Practices for Group Member Assessments, Business Communication Quarterly 65 (March 2002): 9-20.

2. Kwangsu Cho, Christian D. Schunn, and Davida Charney, Commenting on Writing: Typology and Perceived Helpfulness of Comments from Novice Peer Reviewers and Subject Matter Experts, Written Communication 23 (July 2006): 260-294.

3. Keith Topping, Peer Assessment Between Students in Colleges and Universities, Review of Educational Research 68 (Fall 1998): 249-276.

4. Wayne Jensen and Bruce Fischer, Teaching Technical Writing through Student Peer-Evaluation, Journal of Technical Writing and Communication 35 (2005): 95-100.

5. Wayne Jensen and Bruce Fischer, Teaching Technical Writing through Student Peer-Evaluation, Technical Communication 52 (August 2005): 403-404.

6. Nancy Reese-Durham, Peer Evaluation as an Active Learning Technique, Journal of Instructional Psychology 32 (December 2005): 338-346.

7. Cho, Schunn, and Charney, Commenting on Writing.

8. Yining Chen and Hao Lou, Students' Perceptions of Peer Evaluation: An Expectancy Perspective, Journal of Education for Business 79 (May/June 2004): 275-282.

9. Eric M. Wiltse, Using Writing to Predict Students' Choice of Majors, Journalism \& Mass Communication Educator 61 (Summer 2006): 179-194.

10. $\quad$ Elizabeth Birge, The Great Divide, Quill 94 (August 2006): 20-24.

11. Gene A. Budig, Writing: A Necessary Tool: Mr. Budig Issues a Call to Policy Makers, Educators, and Business Leaders to Get Serious about Improving Our Students' Writing Skills, Phi Delta Kappan 87 (May 2006): 663.

12. Paula LaRocque, Words/Language: Don't Forget: Wordiness Is the Chief Enemy of a Clear, Brief, Bright Style, Quill 95 (January/February 2007): 40.

13. Paula LaRocque, Make Your Point; Don't Back into a Sentence, Quill 94 (December 2006): 33.

14. Gene Rose, How to Write Better, State Legislatures 32 (July/August 2006): 64-65.

15. Wiltse, Using Writing to Predict.

16. Mark E. Burbach, Gina S. Matkin, and Susan M. Fritz, Teaching Critical Thinking in an Introductory Leadership Course Utilizing Active Learning Strategies: A Confirmatory Study, College Student Journal 38 (September 2004): 482-493.

17. R.T. Pithers and R. Soden, Critical Thinking in Education: A Review, Educational Research 42 (2000): 237-249.

18. Kathryn S. Lee, Enhancing Critical Thinking in Online Learning, Academic Exchange 9 (Winter 2005): $43-$ 48.

19. Ahrash N. Bissell and Paula P. Lemons, A New Method for Assessing Critical Thinking in the Classroom, BioScience 56 (January 2006): 66-72.

20. Thomas Lauer, Teaching Critical-Thinking Skills Using Course Content Material, Journal of College Science Teaching 34 (May/June 2005): 34-37.

21. Pamela Vesely and John Sherlock, Pedagogical Tools to Develop Critical Thinking, Academic Exchange 9 (Winter 2005): 155-160.

22. Susan Black, Teaching Students to Think Critically, The Education Digest 70 (February 2005): 42-48.

23. Burbach, Matkin, and Fritz, Teaching Critical Thinking.

24. Deidra M. Gammill, Learning the Write Way, The Reading Teacher 59 (May 2006): 754-762.

25. Cho, Schunn, and Charney, Commenting on Writing.

26. Topping, Peer Assessment Between Students. 